\title{
Is Regulatory CAPital a Legitimate, CoMparable AND OBJECTIVE GLOBAL STANDARD? EVIDENCE FROM 51 INSTITUTIONS ACROSS 17 COUNTRIES
}

\author{
Johann Jacobs and Gary van Vuuren \\ School of Economics, North-West University
}

Accepted: September 2013

\begin{abstract}
Capital as an instrument for financial regulation has come under scrutiny since the financial crisis of 2007 to 2010 highlighted some deficiencies in the ability of capital to absorb unexpected losses and the procyclical nature of capital. This scrutiny arises mainly from the perspective that one of the principal objectives of capital requirements is to promote and contribute to financial stability. However, the literature on the topic is scarce almost to the point of non-existence regarding capital's validity as tool to level the playing fields between financial institutions.

The objective of this article is therefore to investigate financial regulations based on capital requirements from the perspective of its goal of providing equal competitive conditions for financial institutions, the attainment of which is based on the assumption that the cost of capital between institutions (and countries) is the same, which might not necessarily be the case. The cost of capital for 51 financial institutions across 17 countries (three institutions per country) is accordingly calculated in this article using original weighted average cost of capital and capital asset pricing models, as well as modified versions of these to include more country-specific factors.

The objective of the article is sought firstly by determining whether the cost of capital is the same among countries and secondly, based on the results, ascertaining whether financial regulations based on capital requirements can therefore realistically achieve this objective of providing equal competitive conditions for financial institutions.
\end{abstract}

Key words: capital requirements, cost of capital, banks, Basel, Solvency II

JEL: F37, 68, G21, 22, 28, O16

1

\section{Introduction}

The objective of the article is to assess whether capital, as a regulatory instrument, can level playing fields between countries based on the cost of capital (COC) between different countries. The COC for 51 banking institutions and financial institutions across 17 countries was calculated using three variants of the capital asset pricing model (CAPM) and the weighted average cost of capital (WACC) models.

The article attempts to investigate the ability of providing level playing fields of financial regulations as a whole, i.e. the Basel Accords (Basel) and Solvency II, based on major similarities between the two sets of regulations.

The article is structured as follows: section 2 introduces the objective of the research.
Section 3 provides a literature review covering the major similarities between banking and insurance regulations, the objectives of financial regulations, and a brief discussion on the history and theory of the cost of capital. The calculation and analysis methods employed in the article are discussed in section 4, while the data and assumptions employed are elucidated in section 5. Section 6 discusses the results and findings of the article before section 7 concludes the research.

\section{2}

\section{Objective}

The objective of the article is to investigate financial regulations based on capital requirements from the perspective of its goal of providing equal competitive conditions for 
financial institutions, the achievement of which is based on the assumption that the COC between financial institutions (and countries) is the same, which might not necessarily be the case.

In essence, the introduction of capital adequacy standards alone may not be able to achieve this goal, as a certain percentage of capital required might, for example, cost one institution in Country A more than it costs another institution in Country B.

The objective of the article is sought firstly by determining whether the COC is the same among countries, and secondly, based on the results, ascertaining whether financial regulations based on capital requirements can therefore realistically achieve this objective.

It may be argued that there may be an offset in the COC (which is based on systematic risks) in some countries in financial institutions' actual capital requirements (which are based on idiosyncratic risks), resulting in some financial institutions being required to hold less capital although this capital might cost them more than it would other financial institutions. However, this article does not attempt to relate the cost of capital back to capital requirements of individual financial institutions, but focuses instead on the cost of capital between financial institutions based in different countries. The relationship between idiosyncratic risks (capital requirements) and systematic risks (the cost of capital) falls outside the scope of the article. It can reasonably be expected that capital requirements based on idiosyncratic risks for financial institutions operating in higher cost of capital environments (based on systematic factors) will not substantially offset higher capital costs because such financial institutions operate in more volatile environments.

It is also important to note that the comparison of the cost of capital is done from an outsider's perspective and not from the perspective of a company wishing to raise capital domestically. It would have been inappropriate had a country risk premium been added if this study were for different companies within the same country. For this reason it is deemed acceptable to add country risk premia to the calculations of the cost of capital to all companies in this study.

\section{3}

\section{Literature review}

This section provides a brief overview of the relevant literature. First, it explains similarities between banking and insurance regulations; second, it provides a description of the objectives of financial regulations, and finally it provides a brief theoretical background to COC models.

\subsection{Similarities between banking and insurance regulations}

The development of banking and insurance regulations over the past 40 years took place in two completely separate streams and conducted by different bodies, yet they share numerous similarities. There is an abundance of literature available on the similarity in characteristics between Basel and Solvency II, including literature by the Bank for International Settlements (BIS) (1999:9; 2006:6); Shadow Financial Regulatory Committees (SFRC) (1999: 2); De Carvalho (2005:7-8); Lind (2005:28); Horcher (2005:257); Van Roy (2005:7); the European Insurance and Re-insurance Federation (CEA) (2006:5); Koch and MacDonald (2006: 312); the Commission of the European Communities (CEC) (2007:3); Sandström (2007: 12); Van Duffel (2008:9); the European Union (EU) (2009:3); Lloyd's (2010:4,8); and Clutterbuck (2011:8), to name but a few. From these sources, high-level similarities between Basel and Solvency II can be drawn, the major ones being that:

- both are based on a similar three-pillar approach, with Pillar 1 being minimum capital requirements and the basis on which both sets of financial regulations are based; and

- both set out to achieve the same broad objectives, including levelling the playing fields between financial institutions.

The remainder of this article is based on these two major similarities between Basel and Solvency II.

\subsection{Levelling of playing fields objective}

The three major objectives of financial regulations are contributing to financial stability, levelling playing fields between financial 
institutions, and being based on more risksensitive measures and tools (BIS, 1999:9; SFRC, 1999:2; De Carvalho, 2005:7-8; Horcher, 2005:257; Van Roy, 2005:7; CEA, 2006:5; Koch \& MacDonald, 2006:312; CEC, 2007:3; Sandström, 2007:12; EU, 2009:3; Lloyd's, 2010:4).

This article focuses on the achievement of the second objective, namely to level playing fields among financial institutions.

\subsection{The cost of capital: brief background and theory}

For the sake of brevity and because they are widely available in literature, the formulas for calculating the components of $\mathrm{COC}$ and the actual COC itself are not included in this article.

The concept of COC has evolved over the past 60 to 65 years and its origins can be traced back to the development of portfolio theory in the 1950s, when Markowitz (1952; 1959) and Roy (1952) started to attempt to relate expected returns to risk. The work done by Modigliani and Miller (1958) is considered as the starting point of the literature on COC (Exley \& Smith, 2006:230), while from the original work done by Markowitz, the CAPM was introduced independently by Sharpe (1964), Lintner (1965), and Mossin (1966), although their work was predated by unpublished work from Treynor in 1961 and 1962 (French, 2003:60).

Since companies fund themselves through a combination of debt and equity (Ernst \& Young, 2011:4), their overall COC is calculated by adding their weighted cost of debt and weighted cost of equity together according to the weights that each component contributes to total capital - this determines the WACC. The objective of companies is to minimise their WACC by determining their optimal capital structure, because in doing so a company will maximise its shareholder value (Brealey, Myers \& Marcus, 2001:572). Much research has been undertaken on the topic of companies' optimal capital structures, including work by, among others, Baxter (1967), Opler, Saron and Titman (1997), Exley and Smith (2006) and Ratshikuni (2009).

The cost of debt is based on the risk-free rate of the country in which the debt is issued plus a credit risk premium according to the riskiness of the country, which is typically easily observable (Brealey et al., 2001:452; Ross, Westerfield and Jaffe, 2003:508; Jenkinson, 2006:3; Madura, 2009:477).

The CAPM is used to calculate the cost of equity and expresses the trade-off between risk and expected return (Madura, 2009:475). Since its introduction, many variations to the original CAPM have been introduced, most notably the Ibbotson Associates Modified CAPM (Annin \& Falaschetti, 1998) and the Fama-French Three-Factor Model (Fama \& French, 2004:25-46).

In contrast, Ross, et al. (2003:502) define the WACC as the sum of the weighted average of the cost of equity and the after-tax cost of debt.

The CAPM and WACC have some inherent weaknesses in their basic forms and these are widely discussed in the literature, most notably in research by Fama and French (2004:13), Perold (2004:16), Jenkinson (2006:7), Sercu (2008: 720), Greenen, Kirisits, Chadwick and Hoeveler (2009:3), Sánchez, Preve and Allende (2010:7) and Villarreal and Córdoba (2010: 11).

As a result of these weaknesses, certain adjustments need to be made to the original CAPM (Villarreal \& Córdoba, 2010:8) and much research has been done on the topic, including research by McCauley and Zimmer (1989), Shoven and Topper (1992), Godfrey and Espinosa (1996), Estrada (2001), Lally (2004) Lambert, Leuz and Verrecchia (2006), Lambert and Verrecchia (2010), and McMorran (2010). The major research that was considered for this article includes the studies of Erb, Harvey and Viskanta (1996), Koedijk, Kool, Schotman, and van Dijk (2002), Harvey (2004; 2005), Sercu (2008), and Villarreal and Córdoba (2010).

The theme of the challenges experienced in calculating the cost of capital for emerging markets surfaces time and again, and it is clear that current models do not yet consider all factors that could impact the cost of equity capital, especially for emerging markets. The relative segregation of emerging markets from global markets along with their increased riskiness remain challenges to obtaining more accurate approximations of the cost of capital and, although many different theories and approaches to determine more accurate results exist, it seems that there is no agreement or uniformity in terms of calculating the cost of 
equity capital among countries (Estrada, 2001: $10)$.

Research on the calculation of the cost of capital across countries includes that of Godfrey and Espinosa (1996) where they adjust beta values to incorporate low correlations among countries (segmentation) and credit spreads into the original CAPM to reflect market segmentation and country risk; Erb et al. (1996) explores alternative measures for calculating expected returns and volatility in developing markets; Lambert, Leuz and Verecchia (2006) and Lambert and Verecchia (2010) where the effect of accounting and general information asymmetries on the cost of capital is explored because information asymmetries would mean that investors would not have access to the same information and therefore not homogenous expectations; McMorran (2010) modifies the original CAPM to take into account a company specific risk premium and an industry premium, while Lally (2004:20-32) provides a description of CAPM models, including international CAPMs. Building on this, Harvey (2004) explores the components of country risk; Sercu (2008:705-748) attempts to add an international diversification dimension to the original CAPM model; and Harvey (2005) critically assesses 12 ways in which the international cost of capital can be calculated, and suggests that the CAPM is used for integrated markets and that a combination of models is used for emerging markets.

Despite these weaknesses and challenges in their application, the CAPM and WACC remain popular methods to calculate COC (Bruner, et al., 1998:15; Brealey, et al., 2001:572; Ross et al., 2003:543).

Villarreal and Córdoba (2010) explore a consistent approach to calculating the $\mathrm{COC}$ in emerging markets and reinforce the need to adjust traditional methods of calculating the COC. The need to adjust it for emerging markets is specifically based on the fact that these markets are typically not fully integrated into global markets and therefore are rendered more inefficient, and also for the country risk component of a developing country.

The following section explains the approach that was adopted for this study, after which the results are presented and discussed.

\section{4 \\ Calculation methods and analysis}

A comparative analysis of the COC is conducted for various institutions across different regions in an attempt achieve the objective of this article.

Three methods were used to calculate the COC among different institutions across different countries:

- the original CAPM and WACC models;

- the original CAPM and WACC models where an equity risk premium is added to the cost of equity; and

- a modified CAPM and WACC model as explained by Villarreal and Córdoba (2010).

In pursuit of its objectives, this article employs the Villarreal and Córdoba (2010) model because it has been specifically developed with the calculation of the cost of capital for developing countries in mind, and the analyses in this paper include a large sample of developing countries. In applying this model to developed countries, it can be reasonably expected that the adjustments made for developing country-specific factors would not distort results for developed countries.

Before providing a brief description of the calculation methods and formulas, it is again necessary to highlight that the calculation of the COC using the CAPM and WACC have some known weaknesses. Two challenges that are often highlighted include the term structure of credit ratings and the time variation of risk premiums (Erb et al., 1996; Harvey, 2004; 2005). These time-dependencies might be as a result of external events and/or shocks and may impact the calculations of the COC. In pursuing its objective, this paper does not explicitly take into account these time effects through advanced regressions analyses as often prescribed. The paper rather focuses on the results of a model that is applied consistently across a sample set of countries instead of focussing on the effect of time on the calculations of the COC.

Without detailing the deduction of this model, the WACC formula used reflects a hypothetical world where taxes, transaction cost and an additional country risk (CR) component are present, and is shown as Equation 1: 


$$
W A C C=\left[\frac{D}{D+E}(1-t) K^{\prime}{ }_{D}\right]+\left(\left(\frac{E}{D+E}\right) K_{E}\right)
$$

where $D$ is the total debt capital of a particular company, $E$ is its total equity capital, $D+E$ its total capital, $K_{D}^{\prime}$ the pre-tax cost of debt, and $K_{E}$ the cost of equity. $K_{D}^{\prime}$ is presented by the cost of debt $\left(K_{D}\right)$ (risk-free rate $\left(R_{F}\right)$ plus intermediation spread) plus a $C R$ premium:

$$
\left.\boldsymbol{K}_{E}=\left\{\left[\boldsymbol{K}_{D}(\mathbf{1}-\boldsymbol{t})\right]+\left[\boldsymbol{\beta}_{E}\left(\boldsymbol{R}_{M^{-}} \boldsymbol{R}_{F}\right)\right]\right\}+\left\{[C R(1-t)]+C R\left(\beta_{E}\right)\right]\right\}
$$

where $\beta_{U}$ is the beta of a specific equity, $R_{M}$ the expected market return and therefore $\left(R_{M}-\right.$ $\left.R_{F}\right)$ the market risk premium, and equity beta $\left(\beta_{\mathrm{E}}\right)$, as explained in Equation 5.

From the original CAPM, it is important to point out that beta is estimated by the quotient of the covariance between the returns of a company's equity returns $\left(R_{E}\right)$ and $R_{M}$, and the variance of the market returns (Sercu, 2008:720):

$$
\boldsymbol{\beta}_{U}=\frac{\operatorname{COVAR}\left(R_{E}, R_{M}\right)}{\operatorname{VAR}\left(R_{M}\right)}
$$

Villarreal and Córdoba (2010:19) refer to the beta in Equation 4 as 'unlevered beta', or $\beta_{U}$, because it is based on equity data only, i.e. it is assumed that the company's capital structure consists of equity only and does not take into account financial leverage. On the other hand, when referring to $\beta_{E}$, Villarreal and Córdoba (2010) refer to a beta which is adjusted by the debt-to-equity ratio $\left(\frac{D}{E}\right)$ of a company, and reflects systematic risk given a company's $\frac{D}{E}$. $\beta_{E}$ is calculated as:

$$
\boldsymbol{\beta}_{E}=\boldsymbol{\beta}_{U}\left[\mathbf{1}+(\mathbf{1}-\boldsymbol{t}) \frac{\boldsymbol{D}}{E}\right]
$$

In turn, Villarreal and Córdoba's (2010:22-23) explanation of levered beta, or $\beta_{\mathrm{L}}$, is the beta of a company where financial leverage is taken into account, or where debt is incorporated into a company's capital structure and is calculated as:

$$
\beta_{L}=\frac{D}{D+E} \beta_{D}+\frac{E}{D+E} \beta_{E}
$$

where $\beta_{D}$ is the beta of debt. For the purpose of this paper it is assumed $\beta_{\mathrm{D}}=0$ as per Villarreal (2004), where it is explained that it can be assumed that the risk of the bondholders is void, to the extent that an institution should always fulfil its obligations toward them irrespective of the ability to pay.

Sometimes the terms 'levered beta', 'unlevered beta', and 'equity beta' are used interchangeably and can lead to much confusion,

$$
\boldsymbol{K}_{\boldsymbol{D}}^{\prime}=\left(\boldsymbol{R}_{F}+\text { intermediation spread }\right)+C R
$$

Similarly, the original calculation of the $K_{E}$ for this model is modified to incorporate a country risk premium that is adjusted to incorporate taxes $(C R(1-t))$ and a non-diversified country risk premium $\left(C R\left(\beta_{E}\right)\right)$ so that:

but for the purpose of this article, the Villarreal and Córdoba (2010) definitions of beta are used throughout.

Now, following from Equation 3, for notational simplicity it is assumed that:

$$
\boldsymbol{C R}(\mathbf{1}-\boldsymbol{t})+\boldsymbol{C R}\left(\boldsymbol{\beta}_{E}\right)=\boldsymbol{C} \boldsymbol{R}^{*}
$$

so that Equation 3 can be re-written as:

$$
K_{E}=\left\{\left[K_{D}(1-t)\right]+\left[\beta_{E}\left(R_{M^{-}} R_{F}\right)\right]\right\}+C R^{*}
$$

Alternatively, the cost of equity can be calculated using $K_{D}^{\prime}$ as a starting point:

$$
K_{E}=K^{\prime}{ }_{D}(1-t)+\beta_{E}\left[\left(R_{M^{-}} R_{F}\right)+C R\right]
$$

From this, a principle of coherence is applied such that the opportunity cost calculation does not depend on the method used, and that there must be consistency between the CAPM and WACC, so that their CAPM formula is modified as follows (note that $\beta_{L}$ is used here):

$$
C A P M=K^{\prime}{ }_{D}(1-t)+\beta_{L}\left[\left(R_{M}-R_{F}\right)+C R\right](10)
$$

With these modifications and the principle of coherence, the results of the WACC and CAPM should be equal and the one can be used to verify the other.

Although this model was developed with the specific aim of addressing challenges experienced in calculating the COC for developing countries, it will be applied to the entire data set used in this article, including developed countries.

\section{5}

\section{Data}

Although the data used in this research were for banks only, therefore explicitly showing the costs of capital for banks across different countries, the results could easily apply to insurance companies also because of the similarities between Basel and Solvency II that were highlighted.

Data selected for this article were based on 
two principles, firstly the need to be representtative of developed and developing markets; and secondly, in order to keep with one of the major assumptions of the Villarreal and Córdoba (2010) model, these markets had to be efficient with at least some degree of sophistication and integration into global markets.

\section{Sample countries and institutions}

The Group of eight countries (G8) (Canada, France, Germany, Italy, Japan, Russia, USA and UK) and a group of countries considered the most important emerging market economies, the so-called 'Outreach 5' (O5) (Brazil, China, India, Mexico and South Africa) were used. Other developing countries including Indonesia, the Philippines, Poland and Turkey were used in addition to the $\mathrm{O} 5$.

From each of these, the largest three banks were selected based on balance-sheet size ${ }^{1}$, all of which can be seen in Appendix A. Financial groups were included in some cases and not purely banks, as the aim of the exercise is not necessarily to calculate the COC among banks only; rather it is to calculate the COC among countries based on banking data.

\section{Time series}

The time period for which data were obtained was for the seven years 2005 to 2011, based on the rationale that these were recent: they would be sufficient to provide meaningful results, and that they included benign and challenging economic conditions.

\section{Risk-free rate $\left(R_{F}\right)$}

The average daily United States (US) ten-year Treasury bond rate was used as a proxy for $R_{F}$ across all countries in this study over the period analysed, i.e. 3.80 per cent (FRED, 2012). This assumption is considered as being rather conservative, considering that most countries that were used in this study will have a higher $R_{F}$ than the US.

\section{Risk-free rate $\left(R_{M}\right)$}

$\boldsymbol{R}_{\boldsymbol{M}}$ is the average returns for the period analysed and were calculated using the returns for each country's equity market using each country's Morgan Stanley Capital International (MSCI) index as a proxy for equity returns.

\section{Equity returns $\left(\boldsymbol{R}_{E}\right)$}

The actual daily equity price movements of each of the institutions analysed in the sample set was obtained from Bloomberg (2012) and the equity returns were calculated for each for the periods analysed.

\section{Intermediation spreads}

The intermediation spreads in this article are determined from data obtained from the Federal Reserve Bank of St Louis Economic Data (FRED, 2012). The categories of the data that were used are reflected in Table 1 and the average spread is the average daily basis points (bps) spread per category above $R_{F}$. Credit rating categories were used in this research, which are illustrated in Table 1. These were applied to each bank as per its credit rating obtained from Fitch Ratings (Fitch, 2012). The US daily average rates per credit rating were applied to all banks that operate in developed countries.

Table 1:

Intermediation spreads

\begin{tabular}{|l|c|}
\hline \multicolumn{1}{|c|}{ Category } & Average spread (bps) \\
\hline US AAA Daily & 58 \\
\hline US AA Daily & 89 \\
\hline US A Daily & 148 \\
\hline US BBB Daily & 216 \\
\hline Emerging markets AAA-A & 134 \\
\hline Emerging markets BBB-B & 257 \\
\hline Emerging markets BB & 490 \\
\hline
\end{tabular}

Source: FRED (2012)

\section{Country risk (CR) spread}

To estimate the CR premium, data were used from Damodaran (2012), who uses credit ratings as a starting point. In this information, local currency credit ratings were used to obtain a default spread in bps above the US 
Treasury bond rate using historical credit data of US corporates and country bonds. This

default spread is illustrated in Table 2:

Table 2

Estimated default spreads by credit rating

\begin{tabular}{|c|c|c|}
\hline Moody's rating & Fitch Rating & Default spread (bps) \\
\hline Aaa & AAA & 25 \\
\hline Aa1 & AA+ & 50 \\
\hline Aa2 & AA & 70 \\
\hline Aa3 & AA- & 85 \\
\hline A1 & A+ & 100 \\
\hline A2 & A & 115 \\
\hline A3 & A- & 150 \\
\hline Baa1 & BBB+ & 175 \\
\hline Baa2 & BBB & 200 \\
\hline Baa3 & BBB- & 240 \\
\hline Ba1 & BB+ & 275 \\
\hline Ba2 & BB & 325 \\
\hline Ba3 & BB- & 400 \\
\hline B1 & B+ & 500 \\
\hline B2 & B & 600 \\
\hline B3 & B- & 700 \\
\hline Caa & CCC & 850 \\
\hline Ca & CC & 1,000 \\
\hline C & D & \\
\hline
\end{tabular}

Source: Modified from Damodaran (2012)

Damodaran (2012) then adds this default spread to a local market risk premium of 5.5 per cent for each country multiplied by an equity-to-bond market volatility factor of 1.5. This represents the total equity market premium for that country. The country risk premium is obtained by subtracting the original market risk premium from this number.

In this article, the same methodology was employed in estimating the country risk premium but for some modifications and additions. Instead of assuming a flat 5.5 per cent local market risk premium for all countries, data were obtained from a survey conducted by Fernández, Aguirreamalloa and Corres (2011), which obtained the market risk premia used by different stakeholders across 56 countries. From this, the average market risk premia for the countries used in this article are indicated in Table 3.

Table 3

Average market risk premia per country

\begin{tabular}{|l|c|c|}
\hline \multicolumn{1}{|c|}{ Country } & $\begin{array}{c}\text { Average local market risk } \\
\text { premium used }\end{array}$ & $\begin{array}{c}\text { Number } \\
\text { ofrespondents }\end{array}$ \\
\hline Brazil & $7.7 \%$ & 35 \\
\hline Canada & $5.9 \%$ & 36 \\
\hline China & $9.4 \%$ & 31 \\
\hline France & $6.0 \%$ & 45 \\
\hline Germany & $5.4 \%$ & 71 \\
\hline India & $8.5 \%$ & 28 \\
\hline Indonesia & $7.3 \%$ & 14 \\
\hline Italy & $5.5 \%$ & 76 \\
\hline Japan & $5.0 \%$ & 14 \\
\hline Mexico & $7.3 \%$ & 56 \\
\hline Philippines & $5.6 \%$ & 6 \\
\hline
\end{tabular}




\begin{tabular}{|l|c|c|}
\hline \multicolumn{1}{|c|}{ Country } & $\begin{array}{c}\text { Average local market risk } \\
\text { premium used }\end{array}$ & $\begin{array}{c}\text { Number } \\
\text { ofrespondents }\end{array}$ \\
\hline Poland & $6.2 \%$ & 28 \\
\hline Russia & $7.5 \%$ & 37 \\
\hline South Africa & $6.3 \%$ & 34 \\
\hline Turkey & $8.1 \%$ & 25 \\
\hline UK & $5.3 \%$ & 112 \\
\hline USA & $5.5 \%$ & 1503 \\
\hline
\end{tabular}

Source: Adapted from Fernández et al. (2011:3)

Bps default spreads were also used in this article (Table 2), but each country's credit rating as measured by Fitch was obtained so that the default spread used for each country was as shown in Table 4.

Table 4

Country default spreads

\begin{tabular}{|l|c|c|}
\hline \multicolumn{1}{|c|}{ Country } & Country rating & Default spread (bps) \\
\hline Brazil & BBB & 175 \\
\hline Canada & AAA & 0 \\
\hline China & A+ & 115 \\
\hline France & AAA & 0 \\
\hline Germany & AAA & 0 \\
\hline India & BBB- & 200 \\
\hline Indonesia & BBB- & 200 \\
\hline Italy & A- & 115 \\
\hline Japan & A+ & 115 \\
\hline Mexico & BBB & 175 \\
\hline Philippines & BB+ & 325 \\
\hline Poland & A- & 115 \\
\hline Russia & BBB & 175 \\
\hline South Africa & BBB+ & 200 \\
\hline Turkey & BB+ & 325 \\
\hline UK & AAA & 0 \\
\hline USA & AAA & 0 \\
\hline
\end{tabular}

Source: Fitch (2012), Damodaran (2012)

For equity-to-bond market volatility spreads, individual country spreads were calculated using the returns for each country's equity market using each country's MSCI index as a proxy for equity returns and the Emerging Markets Bond Index (EMBI) for bond market returns in the developing countries in this article. The Royal Bank of Canada (RBC) Global Corporate Bond Fund ${ }^{2}$ was used as a benchmark for developed markets' bond market returns. The relative volatilities for each of the countries' stock market returns against these bond market return proxies were calculated and used for this input into the model, and the results are presented in Table 5 . The results obtained did not differ much from the original 1.5 value as per Damodaran (2012) and the overall average was 1.66. For the purpose of the present study the average for each of the groups is used, i.e. 1.75 for emerging markets and 1.50 for developed markets.

The country risk rating was obtained as explained earlier, i.e. by subtracting the local market risk premium from the total equity risk premium, the results of which are shown in Table 6. 
Table 5

Equity-to-bond market volatility spreads

\begin{tabular}{|c|c|c|c|}
\hline \multicolumn{2}{|c|}{ Emerging markets } & \multicolumn{2}{|c|}{ Developed markets } \\
\hline Brazil & 1.33 & Canada & 1.82 \\
\hline China & 1.80 & France & 1.21 \\
\hline India & 1.91 & Germany & 1.55 \\
\hline Indonesia & 1.23 & Italy & 1.28 \\
\hline Mexico & 1.53 & Japan & 1.31 \\
\hline Philippines & 1.78 & UK & 1.44 \\
\hline Poland & 2.01 & USA & 1.90 \\
\hline Russia & 1.74 & & \\
\hline South Africa & 2.00 & & \\
\hline Turkey & 1.21 & & \\
\hline $\begin{array}{l}\text { Average: } \\
\text { Emerging markets }\end{array}$ & 1.75 & $\begin{array}{l}\text { Average: } \\
\text { Developed Markets }\end{array}$ & 1.50 \\
\hline Average: & 1.66 & & \\
\hline
\end{tabular}

Source: Bloomberg (2012)

Table 6

Country risk premia

\begin{tabular}{|l|c|c|c|c|c|}
\hline \multicolumn{1}{|c|}{ Country } & $\begin{array}{c}\text { Local market } \\
\text { risk premium }\end{array}$ & $\begin{array}{c}\text { Default } \\
\text { spread (bps) }\end{array}$ & $\begin{array}{c}\text { Equity-to-bond- } \\
\text { market volatility }\end{array}$ & $\begin{array}{c}\text { Total equity risk } \\
\text { premium }\end{array}$ & $\begin{array}{c}\text { Country risk } \\
\text { premium }\end{array}$ \\
\hline Brazil & $7.70 \%$ & 175 & 1.75 & $16.54 \%$ & $8.84 \%$ \\
\hline Canada & $5.90 \%$ & 0 & 1.50 & $8.85 \%$ & $2.95 \%$ \\
\hline China & $9.40 \%$ & 115 & 1.75 & $18.46 \%$ & $9.06 \%$ \\
\hline France & $6.00 \%$ & 0 & 1.50 & $9.00 \%$ & $3.00 \%$ \\
\hline Germany & $5.40 \%$ & 0 & 1.50 & $8.10 \%$ & $2.70 \%$ \\
\hline India & $8.50 \%$ & 200 & 1.75 & $18.38 \%$ & $9.88 \%$ \\
\hline Indonesia & $7.30 \%$ & 200 & 1.75 & $16.28 \%$ & $8.98 \%$ \\
\hline Italy & $5.50 \%$ & 115 & 1.75 & $11.64 \%$ & $6.14 \%$ \\
\hline Japan & $5.00 \%$ & 115 & 1.50 & $9.23 \%$ & $4.23 \%$ \\
\hline Mexico & $7.30 \%$ & 175 & 1.75 & $15.84 \%$ & $8.54 \%$ \\
\hline Philippines & $5.60 \%$ & 325 & 1.75 & $15.49 \%$ & $9.89 \%$ \\
\hline Poland & $6.20 \%$ & 115 & 1.75 & $12.86 \%$ & $6.66 \%$ \\
\hline Russia & $7.50 \%$ & 115 & 1.75 & $15.14 \%$ & $7.64 \%$ \\
\hline South Africa & $6.30 \%$ & 200 & 1.75 & $14.53 \%$ & $8.23 \%$ \\
\hline Turkey & $8.10 \%$ & 325 & 1.75 & $19.86 \%$ & $11.76 \%$ \\
\hline UK & $5.30 \%$ & 0 & 1.50 & $7.95 \%$ & $2.65 \%$ \\
\hline US & $5.50 \%$ & 0 & 1.50 & $8.25 \%$ & $2.75 \%$ \\
\hline SOU & $15 \%$ & $2011)$ & & \\
\hline
\end{tabular}

Source: Adapted from Damodaran (2012) and Fernández et al. (2011), data from Fitch (2012) and Bloomberg (2012)

\section{$\operatorname{Betas}\left(\beta_{U}, \beta_{E}, \beta_{L}\right)$}

$\beta_{U}$ was calculated using the standard variancecovariance approach (Equation 4) in which each bank's monthly equity returns over the period were used to calculate the beta relative to each country's MSCI index described above. $\beta_{E}$ and $\beta_{L}$ were derived from these using the formulas highlighted in Equations 5 and 6 respectively.

\section{Debt-to-equity ratios $(\bar{E})$, total debt $(D)$ and total equity $(E)$}

For banks' $\left(\frac{D}{E}\right), D$ and $E$ data were obtained from Bloomberg (2012), which is where these ratios are calculated.

These data set out above were used as the inputs into calculating the COC according to the three chosen methods explained in section 
4. The results and findings are presented in section 6 .

\section{6}

\section{Results and findings}

The results are presented in the following sections, with each section highlighting the method employed and the results obtained. The first calculation of the $\mathrm{COC}$ was done by employing the original WACC, while the second calculation was done on a similar basis but for an equity market risk premium that was added to the original WACC calculations. These results are denoted by ' $\mathrm{WACC}_{1}$ ' and ' $\mathrm{WACC}_{2}$ ' respectively, both in Table 7 and in the results in Appendix A. Some inputs and the full set of results are attached in Appendix A. The averages of the countries' COC obtained are illustrated in Table 7.

Table 7:

Results: Average COC

\begin{tabular}{|c|c|c|c|}
\hline Average COC & WACC $_{1}$ & $\mathrm{WACC}_{2}$ & WACC and CAPM \\
\hline Brazil & $3.55 \%$ & $5.40 \%$ & $10.28 \%$ \\
\hline China & $2.36 \%$ & $6.20 \%$ & $11.65 \%$ \\
\hline India & $2.77 \%$ & $5.86 \%$ & $12.06 \%$ \\
\hline Indonesia & $1.91 \%$ & $7.16 \%$ & $14.67 \%$ \\
\hline Mexico & $3.42 \%$ & $4.88 \%$ & $10.45 \%$ \\
\hline Philippines & $1.95 \%$ & $5.12 \%$ & $13.84 \%$ \\
\hline Poland & $2.05 \%$ & $4.34 \%$ & $10.08 \%$ \\
\hline Russia & $3.10 \%$ & $5.71 \%$ & $11.67 \%$ \\
\hline South Africa & $2.37 \%$ & $5.93 \%$ & $12.19 \%$ \\
\hline Turkey & $3.11 \%$ & $5.72 \%$ & $15.60 \%$ \\
\hline Emerging markets & $2.66 \%$ & $5.63 \%$ & $12.25 \%$ \\
\hline Canada & $2.81 \%$ & $4.65 \%$ & $5.59 \%$ \\
\hline France & $3.11 \%$ & $3.49 \%$ & $5.51 \%$ \\
\hline Germany & $3.27 \%$ & $3.86 \%$ & $5.61 \%$ \\
\hline Italy & $2.84 \%$ & $3.62 \%$ & $8.03 \%$ \\
\hline Japan & $2.71 \%$ & $3.33 \%$ & $6.02 \%$ \\
\hline United Kingdom & $2.89 \%$ & $3.75 \%$ & $5.66 \%$ \\
\hline United States & $2.06 \%$ & $3.03 \%$ & $4.72 \%$ \\
\hline Developed markets & $2.81 \%$ & $3.68 \%$ & $5.88 \%$ \\
\hline All & $2.72 \%$ & $4.83 \%$ & $9.62 \%$ \\
\hline
\end{tabular}

\subsection{Original WACC (WACC $\left.{ }_{1}\right)$}

Using this calculation method, the cost of debt is calculated by adding a risk premium to the risk-free rate and is denoted by $K_{D 1}^{\prime}$ in Appendix A. In this case, the intermediation spread was added to the cost of debt while the country risk spread was ignored. The original CAPM was employed to calculate the cost of equity $\left(K_{E I}\right)$ and the WACC was calculated by aggregating the weighted averages of these.

In using these CAPM and WACC models, the average $\mathrm{COC}$ was found to be 2.7 per cent across all the countries, and the COC between emerging-market countries and developed markets was closely aligned, with an average COC of
2.7 per cent and 2.8 per cent respectively.

These results highlight some of the weaknesses of the original CAPM and WACC where it is assumed that all countries' financial markets are integrated while ignoring countryspecific risk and taxation. These assumptions drive the relative alignment and low costs of capital between countries, specifically between emerging markets and developed countries.

\subsection{WACC plus equity market premium $\left(\mathrm{WACC}_{2}\right)$}

The second set of results $\left(\mathrm{WACC}_{2}\right)$ was obtained using the same methodology as was used with $\mathrm{WACC}_{1}$, but for an equity market 
risk premium, as per Table 3, that was incorporated into the CAPM calculation of the cost of equity $\left(K_{E 2}\right)$. This addition not only increased the COC (as would be expected), but this increase for emerging markets was incrementally more than that of developed markets.

The WACC in emerging markets increased from the previous average of 2.7 per cent to 5.6 per cent while the WACC for developed markets increased from 2.8 per cent to 3.7 per cent. This incremental increase in emerging markets' $\mathrm{COC}$ is due to the perceived higher risk in their equity markets, also indicating the effect on the COC where markets are not fully integrated globally. The results of $\mathrm{WACC}_{2}$ indicate that, if country-specific factors are considered, the COC between countries differs and that there is a larger difference between the COC of developing countries and that of developed countries.

\subsection{Villarreal and Córdoba models (WACC and CAPM)}

Villarreal and Córdoba (2010) argue that the results of the WACC and the CAPM should be equal if their principles of intermediation spreads, country risk, taxation, and different betas used are applied correctly, which was the case in this article (WACC and CAPM were verified as per Appendix A).

The cost of debt used in these models is denoted as $K_{D}{ }_{D}$ and the cost of equity used as $K_{E}$ in Appendix A. $C R$ and $C R^{*}$ are used as the country risk spreads as explained in Equations 7,8 , and 9 .

The results obtained with these models show that an even larger gulf in the COC between developed countries and emerging markets develops as more factors are considered for COC calculations as illustrated in Figure 1.

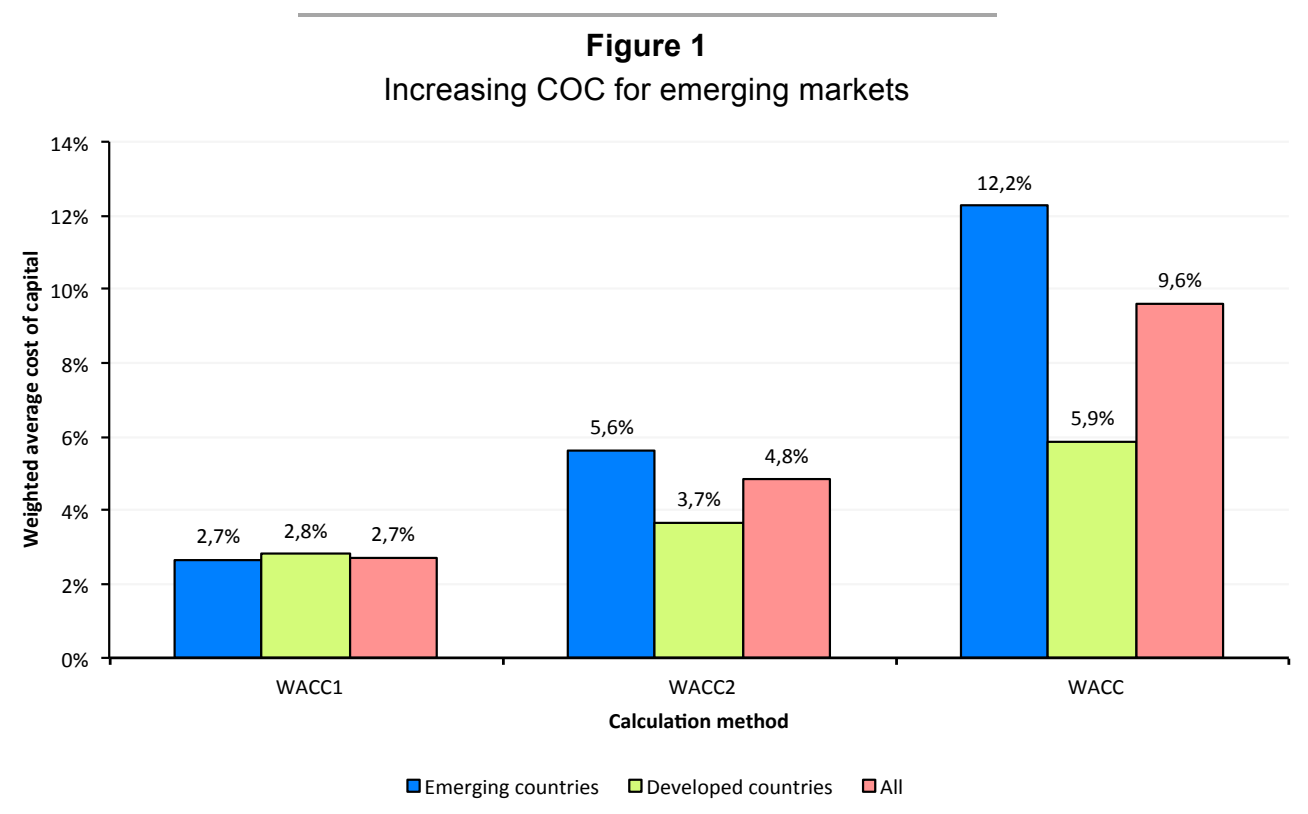

Source: Compiled by the author.

The average COC of emerging markets more than doubled from 5.6 per cent to 12.3 per cent, while the COC for developed countries increased from 3.7 per cent to 5.9 per cent. Again, it may be deduced from the results that emerging markets are still not fully integrated into global financial markets and that they are more risky than developed markets. The COC among developing countries remained relatively closely aligned when using this model.

The conclusions that can be drawn from these results are discussed in the following section. 
7

\section{Conclusions}

From the results obtained, a clear pattern emerged, namely that the COC increased significantly more in emerging markets than in developed countries when additional countryspecific factors were included in the calculations. This provides further results from which certain conclusions can be drawn.

\subsection{Different COC between emerging markets and developed markets}

The results obtained from the $\mathrm{COC}$ calculations indicate that the COC increases at an increasing rate between developed countries and emerging markets as more countryspecific factors are used as inputs to the models.

This illustrates the well-known fact that emerging markets are not fully integrated into global markets and that there is a difference between the COC in emerging markets and in developed markets. The results in this article may even understate the extent of this, because there may be a potentially infinite list of factors that could be included as additional country-specific factors which may accentuate this gap in the COC.

\subsection{Unequal benefits}

Based on the results, an argument can be made that financial regulations based on capital requirements are biased towards developedmarket economies. Financial regulations are designed in developed countries mainly for the developed world where financial markets are closely integrated (and, from the results in this article, their COC) while nuances in developing countries are not taken into account. Developing countries are often socially and politically relatively worse off than developed countries already. Accordingly, in complying with financial regulations that do not apply to them or that do not consider nuances in their domestic markets, developing countries may find themselves being disadvantaged compared to their counterparts in developed countries.

Therefore, financial regulations based on capital requirements may be a useful tool to ensure equal footing among financial institutions in developed countries, but not across all markets. Essentially, as long as certain markets pay more for their capital than others, financial regulations, which aim to ensure no competitive advantage among financial institutions through using capital requirements, cannot fully realise this objective.

\subsection{Capital as regulatory instrument}

Following the financial crisis, the ability of capital as regulatory tool to contribute to financial stability through acting as a buffer against unexpected losses has been questioned because of its procyclical nature (e.g. Atik, 2011; Dowd, Hutchinson, Ashby \& Hinchliffe, 2011).

Adding impetus to the previous finding, the results of this article may further strengthen arguments against capital as an instrument for financial regulation based on its inability to fulfil the objective of levelling playing fields between countries and institutions, in addition to the argument from a financial stability perspective.

\subsection{Development of financial regulations}

The development of financial regulations should take into account more country-specific factors to ensure that countries are not forced into competitive disadvantages in complying with financial regulations. It could therefore be useful to have more emerging-market representation in the design and conceptualisation of financial regulations to take into account certain country-specific factors. Financial regulations should also be flexible enough to allow for emerging markets to simply not comply with certain requirements that may significantly penalise them for factors over which they have no control. In addition, policymakers in emerging markets should engage with regulatory bodies on nuances where complying with certain regulations might disadvantage them.

The alignment of financial regulations between developed and emerging markets is further complicated in view of the fact that, from a regulatory arbitrage perspective, banks and insurers operate on equal grounds (European Central Bank (ECB), 2007; AlDarwish, Hafeman, Impavido, Kemp \& O’Malley, 2011). It is therefore imperative that in attempting to ensure consistency between 
Basel and Solvency II, regulators should pay heed to the challenges faced by emergingmarket countries when the COC and countryspecific factors are considered.

\subsection{Relevance to Solvency II}

Although the data used for this research related specifically to banks and banking groups, it is reasonable to infer that the results will apply to all financial institutions and not only to banks, as the majority of the inputs used in the models were not bank-specific. In addition, these results, findings and conclusions apply to Solvency II based on the similarities between Basel and Solvency II that were highlighted in section 0 .

With this in mind and with the implementation of Solvency II being an ongoing task, the opportunity exists for emergingmarket countries and their regulators to highlight some of the more specific factors and influences in their markets that might place them at a disadvantage compared to developed countries.

\subsection{Usefulness of the Villarreal and Córdoba model}

A further finding is not related to the objective of this article and relates to the methodology employed to calculate the cost of capital as suggested by Villarreal and Córdoba (2010). The results affirm earlier work and confirm the theoretical foundations of their work and the usability of their models for a study of this nature.

\section{Endnotes}

1 In some cases banks not representing the three largest balance sheets in a specific country were selected based on data availability. In this regard, according to banks' size, for Mexico numbers 1, 3 and 4 were used; for Russia 1, 2 and 6; for Turkey 1, 2 and 4; and for Germany 1, 4 and 6.

2 RBC Global Corporate Bond Fund (the Fund) is an open-end fund incorporated in Canada. The Fund seeks to provide a high level of interest income with the potential for modest capital growth by investing primarily in global corporate bonds. The Fund will invest in investment grade corporate debt securities from anywhere around the world.

\section{References}

AL-DARWISH, A., HAFEMAN, M., IMPAVIDO, G., KEMP, M. \& O’MALLEY, P. 2011. Possible unintended consequences of Basel III and Solvency II. International Monetary Fund (IMF) Working Paper: WP/11/187. August. Available at: http://www.imf.org/external/pubs/ft/wp/2011/wp11187.pdf [accessed 2012-06-15].

ANNIN, M. \& FALASCHETTI, D. 1998. Equity risk premiums. Valuation Strategies, January/February. Thomson Reuters, New York City, New York, United States of America. Available at: http://corporate. morningstar.com/ib/documents/MethodologyDocuments/IBBAssociates/EquityRiskPremiums.pdf [accessed 2012-07-27].

ATIK, J. 2011. Basel II: A post-crisis post-mortem. Transnational law and contemporary problems: A journal of the University of Iowa College of Law, 19:731. Iowa, United States of America. Available at: http://papers.ssrn.com/sol3/Delivery.cfm/SSRN_ID1725004_code332621.pdf?abstractid=1725004\&mirid=3 [accessed 2012-06-17].

BANK FOR INTERNATIONAL SETTLEMENTS, Basel Committee on banking supervision (BCBS). 2006. International convergence of capital measurement and capital standards, A Revised Framework. July. Basel, Switzerland.

BANK FOR INTERNATIONAL SETTLEMENTS, Basel Committee on banking supervision (BCBS). 1999. A new capital adequacy framework, consultative paper issued by the Basel Committee on Banking Supervision. June. Basel, Switzerland. Available at: http://www.bis.org/publ/bcbs50.htm [accessed 2012-06-13].

BAXTER, N.D. 1967.Leverage, risk of ruin, and the cost of capital. The Journal of Finance, 22(3):395403.September. Available at: http://www.jstor.org/stable/2978892 [accessed 2012-07-20].

BIS see BANK FOR INTERNATIONAL SETTLEMENTS.

BLOOMBERG, L.P. 2012.Historical equity price and index data for companies used in this article. Retrieved 20-22 August 2012 from Bloomberg Database.

BREALEY, R.A., MYERS, S.C. \& MARCUS, A.J. 2001.Fundamentals of corporate finance, $\left(3^{\text {rd }} \mathrm{ed}\right.$.) The McGraw-Hill Companies, Inc. United States of America. 
BRUNER, R.F., EADES, K.M., HARRIS, R.S. \& HIGGINS, R.C. 1998. Best practices in estimating the cost of capital: Survey and synthesis. Journal of Applied Finance (formerly Financial Practice and Education) Spring/Summer. Available at: http://www.pageout.net/user/www/j/o/jostokes/BRUNEREst_Cost_of_ Capital.pdf [accessed 2012-08-03].

CEA see COMITÉ EUROPÉEN DES ASSURANCES, European Insurance and Re-insurance Federation. CEC see COMMISSION OF THE EUROPEAN COMMUNITIES

CLUTTERBUCK, N. 2011.Solvency II. Presentation given at the International Association of Engineering Insurers (IMIA) Annual Conference. 21 September. Amsterdam, Netherlands. Available at: http://www.imia. com/downloads/guest presentations/GP28 2011.pdf [accessed 2012-06-23].

COMITÉ EUROPÉEN DES ASSURANCES, European insurance and re-insurance federation (CEA). 2006. Solvency II introductory guide. June. Brussels, Belgium. Available at: http://www.cea.eu/uploads/ DocumentsLibrary/documents/Solvency\%20II\%20-\%20Introductory\%20Guide.pdf [accessed 2012-06-15]. COMMISSION OF THE EUROPEAN COMMUNITIES (CEC). 2007. Accompanying document to the proposal for a Directive concerning life assurance on the taking up and pursuit of the business of Insurance and Reinsurance (Solvency II). Staff working document: Executive summary of the impact assessment.10 July. Brussels, Belgium. Available at: http://ec.europa.eu/internal_market/insurance/docs/solvency/ impactassess/executive-summary_en.pdf [accessed 2012-06-27].

DAMODARAN ONLINE see DAMODARAN, A.

DAMODARAN, A. 2012.Damodaranonline: The data page. Various data sets used in this article. Available at: http://w4.stern.nyu.edu/ adamodar/New_Home_Page/data.html [accessed 2012-08-09].

DE CARVALHO, F., J. 2005. Basel II: A critical assessment. Working paper 6 of Universidade Federal do Paraná, Department of Economics. 17 March. Curitiba, Brazil. Available at: http://www.economiaetecnologia. ufpr.br/textos_discussao/texto_para_discussao_ano_2005_texto_02.pdf [accessed 2012-06-24].

DOWD, K., HUTCHINSON, K., ASHBY, S. \& HINCHLIFFE, J. M. 2011. Capital inadequacies: The dismal failure of the Basel regime of bank capital regulation. Cato Institute Policy Analysis No. 681. 29 July. Washington D.C., United States of America. Available at: http://www.cato.org/publications/policyanalysis/capital-inadequacies-dismal-failure-basel-regime-bank-capital-regulation [accessed 2012-06-20]. ECB see EUROPEAN CENTRAL BANK.

ERB, C.B., HARVEY, C.R. \& VISKANTA, T.E. 1996. Expected returns and volatility in 135 countries: Projected returns and variances in countries with and without equity markets. February. Available at: http://papers.ssrn.com/sol3/Delivery.cfm/SSRN_ID871253_code16198.pdf?abstractid=871253\&mirid=3 [accessed 2012-08-03].

ERNST \& YOUNG. 2011. Cost of capital: Its application in electricity regulation presentation. 24 August. Available at: http://www.consumeraction.org.au/downloads/Session1-JoannaIfield.pdf [accessed 2012-08-01].

ESTRADA, J. 2001. The cost of capital in emerging markets: A downside risk approach (II). March. Instituto de Estudios Superiores de la Empresa (IESE) Business School, University of Navarra. Barcelona, Spain. Available at: http://citeseerx.ist.psu.edu/viewdoc/download?doi=10.1.1.203.4883\&rep=rep1\&type=pdf [accessed 2012-07-31].

EU see EUROPEAN UNION.

EUROPEAN CENTRAL BANK (ECB). 2007. Potential impact of Solvency II on financial stability. July. Frankfurt, Germany. Available at: http://ec.europa.eu/internal_market/insurance/docs/solvency/impactassess/ annex-c07_en.pdf [accessed 2012-07-05].

EUROPEAN UNION. 2009. Official journal of the European Union. Directive 2009/136/EC of the European parliament and of the council of 25 November 2009 on the taking up and pursuit of the business of insurance and reinsurance (Solvency II). 25 November. Brussels, Belgium. Available at: http://www.lloyds.com/TheMarket/Operating-at-Lloyds/Solvency-II/Legislative-developments/ /media/Files/The\%20Market/ Operating\%20at\%20Lloyds/Solvency\%20II/Solvency\%20II\%20Directive.pdf [accessed 2012-06-20].

EXLEY, C.J. \& SMITH, A.D. 2006. The cost of capital for financial firms. British Actuarial Journal, 12(1):229-301. Available at: http://journals.cambridge.org/action/displayAbstract?fromPage=online\&aid= 8249067\& fulltextType=RA\&fileId=S1357321700004761 [accessed 2012-08-03].

FAMA, E.F. \& FRENCH, K.R. 2004. The capital asset pricing model: Theory and evidence. Journal of Economic Perspectives, 18(3):25-46. Available at: http://www-personal.umich.edu/ kathrynd/JEP. FamaandFrench.pdf [accessed 2012-07-27]. 
FEDERAL RESERVE BANK OF ST. LOUIS ECONOMIC DATA (FRED). 2012. Corporate bonds public data. Federal Reserve Bank of St. Louis, St. Louis, United States of America. Available at: http://research. stlouisfed.org/fred2/categories/32348/downloaddata [accessed 2012-08-14].

FERNÁNDEZ, P., AGUIRREAMALLOA, J. \& CORRES, L. 2011. Market risk premium used in 56 countries in 2011: A survey with 6,014 answers. Working Paper WP-920. May. Instituto de Estudios Superiores de la Empresa (IESE) Business School, University of Navarra. Barcelona, Spain. Available at: $\mathrm{http} / /$ papers.ssrn.com/sol3/Delivery.cfm/SSRN_ID1822182_code12696.pdf?abstractid=1822182\&mirid=3 [accessed 2012-08-03].

FITCH RATINGS (FITCH). 2012. Company and country ratings for companies and countries used in this article. Retrieved 16 July 2012 from Fitch Database.

FITCH see FITCH RATINGS.

FRED see FEDERAL RESERVE BANK OF ST. LOUIS ECONOMIC DATA.

FRENCH, C. W. 2003. The Treynor capital asset pricing model. Journal of Investment Management, 1(2): 60-72. Available at: http://ciber.fuqua.duke.edu/ charvey/Teaching/BA453_2006/French_Treynor_ CAPM.pdf [accessed 2012-08-06].

GODFREY, S. \& ESPINOSA, R. 1996. A practical approach to calculating costs of equity for investments in emerging markets. Journal of Applied Corporate Finance, 9(3):80-90. Available at: http://ideas.repec.org/ a/bla/jacrfn/v9y1996i3p80-90.html [accessed 2012-08-01].

GREENEN, M., KIRISITS, M., CHADWICK, J. \& HOEVELER, C. 2009. The real cost of capital. July. Harlingwood Equity Partners, San Diego, California, United States of America. Available at: http://www.harlingwood.com/Docs/harlingwood-r3-whitePaper.pdf [accessed 2012-07-10].

HARVEY, C.R. 2004. Country risk components, the cost of capital, and returns in emerging markets. November. Duke University, North Carolina, United States of America. Available at: http://papers.ssrn.com/ sol3/papers.cfm?abstract_id $=620710$ [accessed 2012-06-28]

HARVEY, C. R. 2005. 12 Ways to calculate the international cost of capital. 14 October. Duke University, North Carolina, United States of America. Available at: http://faculty.fuqua.duke.edu/ charvey/Teaching/ BA456_2006/Harvey_12_ways_to.pdf [accessed 2012-06-27].

HORCHER, K. 2005. Essentials of financial risk management. John Wiley and Sons Inc. New Jersey, United States of America.

JENKINSON, T. 2006. Regulation and the cost of capital. Forthcoming article in the Handbook on Economic Regulation. Available at: http://xfi.exeter.ac.uk/conferences/costofcapital/papers/jenkinson_regulation_and_ the_cost_of_capital.pdf [accessed 2012-07-10].

KOCH, T.W. \& MACDONALD, S.S. 2006. Management of Banking, $\left(6^{\text {th }}\right.$ int. student ed.) Thomson SouthWestern, a part of the Thomson Corporation. Mason, United States of America.

KOEDIJK, K.G., KOOL, C.J.M., SCHOTMAN, P.C. \& VAN DIJK, M.A. 2002. The cost of capital in international financial markets: Local or global? Journal of International Money and Finance, 21(6):905-929. Available at: http://arno.unimaas.nl/show.cgi?fid=2556 [accessed 2012-08-05].

LALLY, M. 2004. The cost of capital for regulated entities - report prepared for the Queensland Competition Authority. 26 February. School of Economics and Finance, Victoria University of Wellington. Wellington, New Zealand. Available at: http://www.qca.org.au/files/LallyReport_CostofCapital.pdf [accessed 2012-08-03]

LAMBERT, R. \& VERRECHIA, R.E. 2010. Cost of capital in imperfect competition settings. January. The Wharton School, University of Pennsylvania. Philadelphia, United States of America. Available at: http://faculty.chicagobooth.edu/workshops/accounting/archive/pdf/LV.01.12.10.pdf [accessed 2012-07-21].

LAMBERT, R., LEUZ, C. \& VERRECHIA, R.E. 2006. Accounting information, disclosure, and the cost of capital. August. Available at: http://papers.ssrn.com/sol3/papers.cfm?abstract_id=823504 [accessed 2012-07-20].

LIND, G. 2005. Basel II - The new framework for bank capital. Riksbank Economic Review 2005-02.22

June. Stockholm, Sweden. Available at: http://www.riksbank.se/Upload/Dokument_riksbank/Kat_publicerat/ PoV_sve/2005_2e.pdf [accessed 2012-07-05].

LINTNER, J. 1965. The valuation of risk assets and the selection of risky investments in stock portfolios and capital budgets. The Review of Economics and Statistics, 47(1):13-37. February. Available at: http://finance. martinsewell.com/capm/Lintner1965a.pdf [accessed 2012-08-04]. 
LLOYD’S. 2010. Solvency II: An overview. July. London, United Kingdom. Available at: http://www.lloyds. com/ /media/Files/The\%20Market/Operating\%20at\%20Lloyds/Solvency\%20II/Solvency\%20II\%20Introduct ion\%20July\%202010.pdf [accessed 2012-06-25].

MADURA, J. 2009. International financial management, (abr. $9^{\text {th }}$ ed.) South-Western/Cengage Learning, Ohio, United States of America.

MARKOWITZ, H. 1952. The utility of wealth. The Journal of Political Economy, 60(2):151-158. Available at: http://cowles.econ.yale.edu/P/cp/p00b/p0057.pdf [accessed 2012-07-31].

MARKOWITZ, H. 1959. Portfolio selection: Efficient diversification of investments. February. John Wiley and Sons Inc., New York. Available at: http://cowles.econ.yale.edu/P/cm/m16/m16-all.pdf [accessed 2012-08-04].

McCAULEY, R.N. \& ZIMMER, S.A. 1989. Explaining international differences in the cost of capital. Federal Reserve Bank of New York (FRBNY) Quarterly Review, 14(2):7-28. Available at:

$\mathrm{http} / / /$ www.newyorkfed.org/research/quarterly_review/1989v14/v14n2article2.pdf [accessed 2012-07-23].

McMORRAN, J. 2010. Cost of capital - Trends, tools and applications. Available at: http://www.pncpa.com/ admin/files/resources/Cost_of_Capital_2010.pdf [accessed 2012-07-17].

MODIGLIANI, F. \& MILLER, M.H. 1958. The cost of capital, corporation finance and the theory of investment. The American Economic Review, 48(3):261-297. Available at: http://www.his.se/PageFiles/ 17648/modiglianiandmiller1958.pdf [accessed 2012-07-31].

MOSSIN, J. 1966. Equilibrium in a capital market asset. Econometrica, 34(4):768-783. Available at: http://efinance.org.cn/cn/fm/Equilibrium\%20in\%20a\%20Capital\%20Asset\%20Market.pdf [accessed 2012-08-07].

OPLER, C., SARON, M. \& TITMAN, S. 1997. Designing capital structure to create shareholder value. Journal of Applied Corporate Finance, 10.1(Spring). Available at: http://finance5.net/download.php?id=6 [accessed 2012-07-28].

PEROLD, A.F. 2004. The capital asset pricing model. Journal of Economic Perspectives, 18(3):3-24. Available at: http://www.faculty.fairfield.edu/NLAOPODIS/the\%20capm.pdf [accessed 2012-07-29].

RATSHIKUNI, M.N. 2009. Optimal capital structure for JSE listed companies. Research project submitted to the Gordon Institute of Business Science, University of Pretoria, in partial fulfilment of the requirements for the degree of master of business administration. November. Gordon Institute of Business Science, University of Pretoria, Pretoria. Available at: http://upetd.up.ac.za/thesis/available/etd-05072010-145024/unrestricted/ dissertation.pdf [accessed 2012-08-07].

ROSS, S.A., WESTERFIELD, R.W. \& JAFFE, J. 2003. Fundamentals of corporate finance, $\left(6^{\text {th }}\right.$ ed.alt.ed.) The McGraw-Hill Companies, Inc. USA.

ROY, A.D. 1952. Safety first and the holding of assets. Econometrica, 20(3):431-449.July. Available at: http://www.jstor.org/discover/10.2307/1907413?uid=3739368\&uid=2129\&uid=2134\&uid=2\&uid=70\&uid=4 $\&$ sid=21101121810587 [accessed 2012-08-04].

SÁNCHEZ, J.G., PREVE, L. \& ALLENDE, V.S. 2010. Asymmetry and the cost of capital. December. IAE Business School, Universidad Austral. Buenos Aires, Argentina. Available at: http://www.iae.edu.ar/pi/ Documentos\%20Investigacin/Research\%20Seminars/Asymmetry\%20and $\% 20$ the $\% 20$ cost $\% 20$ of $\% 20$ capital JGS-LP-VS.pdf [accessed 2012-07-23].

SANDSTRÖM, A. 2007. EU Solvency II - A non-life perspective. Presentation given at CAS spring meeting. 19 June. Orlando, Florida, United States of America. Available at: http://www.slideworld.org/ viewslides.aspx/EU-Solvency-II-\%E2\%80\%93-a-non-life-perspective-ppt-2546760 [accessed 2012-06-30]. SERCU, P. 2008. International finance: Putting theory into practice. July. Leuven School of Business and Economics, Katholieke Universiteit, Leuven. Leuven, Belgium. Available at: http://vincer.weebly.com/ uploads/2/2/9/0/2290177/international_finance.pdf [accessed 2012-08-06].

SFRC see SHADOW FINANCIAL REGULATORY COMMITTEES.

SHADOW FINANCIAL REGULATORY COMMITTEES (SFRC). 1999. Improving the Basle Committee's new capital adequacy framework, Joint statement by the shadow financial regulatory committees of Europe, Japan and the US. 14 June. New York, United States of America. Available at: http://www.econ.keio.ac.jp/ staff/masaya//shadow/article/jointstate_1.doc [accessed 2012-06-21].

SHARPE, W.F. 1964. Capital asset prices: A theory of market equilibrium under conditions of risk. The Journal of Finance, 19(3):425-442. Available at: http://efinance.org.cn/cn/fm/Capital\%20Asset\%20 
Prices\%20A\%20Theory\%20of\%20Market\%20Equilibrium\%20under\%20Conditions\%20of\%20Risk.pdf [accessed 2012-08-03].

SHOVEN, J.B. \& TOPPER, M. 1992. The cost of capital in Canada, the United States, and Japan. Canada-US Tax Comparisons (pp. 217-235). January. University of Chicago Press. Chicago, United States of America. Available at: http://www.nber.org/chapters/c7483.pdf [accessed 2012-07-12].

VAN DUFFEL, S. 2008. Solvency II: A critical view with a focus on risk aggregation. X-Act Consulting. Antwerp, Belgium. Available at: http://www.x-act-consulting.com/files/cbfa-september-2008.pdf [accessed 2012-06-10].

VAN ROY, P. 2005. Credit-ratings and the standardised approach to credit risk in Basel II, European Central Bank Working Paper Series No. 517.August. European Central Bank. Frankfurt, Germany. Available at: http://www.ecb.int/pub/pdf/scpwps/ecbwp517.pdf [accessed 2012-06-12].

VILLARREAL, J. 2004. Notas para ajustar el riesgo sistemático por el apalancamiento financiero. Available at: http://www.minminas.gov.co/minminas/downloads/archivosEventos/6754.pdf [accessed 2013-07-08].

VILLARREAL, J. \& CÓRDOBA, M.J. 2010.A consistent methodology for the calculation of the cost of capital in emerging markets. July. Available at: http://papers.ssrn.com/sol3/papers.cfm?abstract_id=1663845 [accessed 2012-08-02]. 


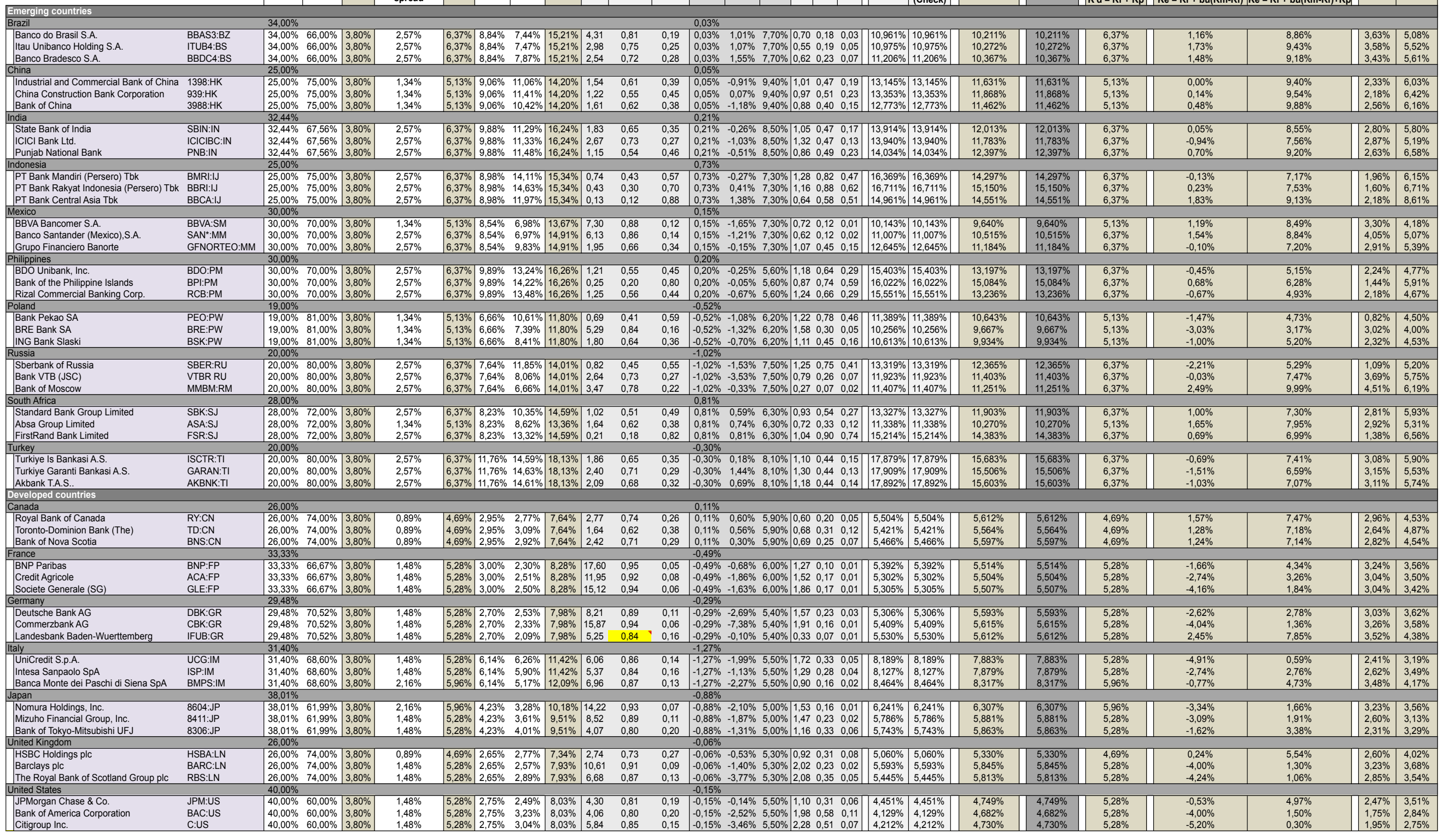

